\title{
PENGARUH KOMUNIKASI ANTARPRIBADI DAN KECERDASAN EMOSIONAL TERHADAP KINERJA PADA KARYAWAN DI PT. ASURANSI RAYA
}

\author{
Wanda Griya Pudhag Wangi* \\ Roni Faslah**
}

\begin{abstract}
The research aims to determine whether there is influence between Interpersonal Communication and Emotional Intelligence to Employee Performance in PT. Asuransi Raya. The method used is survey method with the path analysis. Test requirements analysis is used to find the regression equation obtained is $Y=0.417$ Structure $X 1+X 2+0.3240 .6140 .614 \varepsilon 2$ and $R 2 y \times 2 x 1$ $=X 1$ where $X 2=0.397+0.842=0.158 \varepsilon 1$ and $R 2 \times 2 \times 1$. The results of both hypothesis test variables of interpersonal communication and emotional intelligence) simultaneously have an influence on employee performance, each independent variable is interpersonal communication and emotional intelligence has a significant influence on the dependent variable is the performance of employees.
\end{abstract}

Key words: Interpersonal Communication, Emotional Intelligence, Employee, Performance.

\section{PENDAHULUAN}

Perkembangan ekonomi yang semakin maju menyebabkan persaingan dunia usaha semakin pesat, hal ini menyebabkan perusahaan bersainmemperoleh

\footnotetext{
* Wanda Griya Pudhag Wangi adalah Alumni Fakultas Ekonomi Universitas Negeri Jakarta

** Roni Faslah adalah dosen Fakultas Ekonomi Universitas Negeri Jakarta
}

keuntungan yang merupakan tujuan perusahaan untuk mempertahankan eksistensi usahanya. Setiap perusahaan selalu berusaha untuk meningkatkan kinerja para karyawannya yang pada akhirnya meningkatkan kinerja dari perusahaan itu sendiri. Berbicara tentang kinerja perusahaan, yang berarti memberikan peningkatan dan pengembangan pencapaian 
pekerjaan agar menjadi lebih berkualitas. Dan untuk itu tidak dapat dilihat dari satu unsur, tetapi dari semua unsur, mulai dari awal sampai akhir pekerjaan. Dari keseluruhan proses, ada satu unsur penting yang berperan sebagai penentu berjalan tidaknya pekerjaan yaitu sumber daya manusia.

Manusia sebagai karyawan merupakan aset yang sangat berharga bagi perusahaan. Hal ini dikarenakan manusia dapat menghasilkan sesuatu yang berguna, yang dalam konteks ini adalah pencapaian hasil suatu pekerjaan yang mengarah pada pencapaian tujuan perusahaan. Hal tersebut dapat dilihat dari tersedianya alat-alat berteknologi canggih yang kurang memberikan manfaat maksimal jika karyawan tidak mampu mengoperasikannya.

Berawal dari pemahaman pentimgnya unsur manusia maka diperlukan adanya pengelolaan yang tepat terhadap karyawan, sehingga karyawan dapat memberikan hasil kerja terbaiknya yang berdampak bagi kelancaran perusahaan dalam memperoleh hasil yang optimal. Hal ini ditandai dengan penggunaan sumber daya yang tersedia secara efektif dan efisien serta penilaian yang objektif tentang pencapaian hasil kerja dari karyawan. Sebaliknya, tanpa pengelolaan yang tepat perusahaan akan dihadapkan pada berbagai persoalan rumit yang mengakibatkan terjadinya ketidaklancaran dalam menjalankan perusahaan. Jika keadaan ini dibiarkan maka perusahaan akan mengalami kehancuran, ditandai dengan semakin menurunnya kinerja karyawan.

Banyak faktor yang dapat mempengaruhi tinggi rendahnya kinerja seoarang karyawan, diantaranya adalah faktor komunikasi antarpribadi. Perlu diperhatikan bahwa hubungan yang baik antara sesame karyawan maupun atasan akan meningkatkan motivasi karyawan untuk memberikan kemampuan terbaik yang dimilikinya karena dengan terbinanya hubungan yang baik di dalam perusahaan akan membuat komunikasi antarpribadi di dalamnya menjadi nyaman dan karyawan akan merasa dihargai sehingga kinerja karyawannya akan meningkat. Sebaliknya, jika tidak tercipta komunikasi antarpribadi yang baik, karyawan akan merasa tidak nyaman dalam bekerja karena merasa disepelekan akan menurunkan kinerja karyawan itu sendiri.

Faktor lain yang tidak kalah pentingnya dalam mempengaruhi kinerja karyawan adalah kecerdasan emosi. Setiap harinya para 
karyawan akan selalu bertemu dengan permasalahan baru baik terhadap sesama karyawan/atasan/klien ataupun terhadap pekerjaannya. Disini karyawan harus bisa menemui jalan keluar/pemecahan masalah dari permasalahan yang timbul dan untuk itu diperlukan kecerdasan emosi yang baik untuk menyelesaikan masalah agar tidak terjadi keributan, ketegangan, atau keretakan diantara para karyawan/atasan dan klien. Karena jika terjadi keretakan diantara para karyawan/atasan dan klien, mereka akan merasa tidak nyaman dalam pekerajannya sehingga dapat menurunkan kinerjanya bagi perusahaan.

Sebaliknya karyawan yang cerdas emosi, mampu menyelesaikan masalah yang timbul dengan kepala dingin sehingga tidak menimbulkan ketegangan atau permasalahan baru terhadap karyawan lain/atasan dan pada akhirnya tercipta hubungan yang harmonis serta kenyamanan dalam bekerja yang dampaknya akan meningkatkan kinerja karyawan.

Setiap

perusahaan

menginginkan kinerja yang maksimal dari para karyawannya. Oleh karena itu, perusahaan selalu berusaha menciptakan hubungan yang baik antar karyawannya dengan berkomunikasi antarpribadi yang positif dan membina kecerdasan emosi agar tercipta kenyamanan di lingkungan karyawan sehingga karyawan dapat memberikan kinerja yang maksimal tercermin dari hasil pekerjaan yang diberikan kepada karyawan itu sendiri.

\section{Perumusan Masalah}

1. Apakah terdapat pengaruh komunikasi antarpribadi terhadap kinerja karyawan di PT. Asuransi Raya ?

2. Apakah terdapat pengaruh kecerdasan emosional terhadap kinerja karyawan di PT. Asuransi Raya ?

3. Apakah terdapat pengaruh komunikasi antarpribadi dan kecerdasan emosional secara bersama terhadap kinerja karyawan di PT. Asuransi Raya ?

\section{TINJAUAN PUSTAKA}

\section{Kinerja}

Setiap perusahaan selalu berupaya agar karyawannya dapat memberikan kinerja yang terbaik dari tugas-tugas yang telah dipercayakannya agar tercapai tujuan perusahaan yang telah ditetapkan sebelumnya. Untuk itu perlu dilakukan penilaian dari hasilhasil kerja yang telah dilakukan. 
Kinerja karyawan dapat dinilai dari berbagai aspek. Mulai dari tingkat kedisiplinan hingga hasil akhir atau pencapaian dari seorang karyawan dalam pekerjaan yang menjadi tanggung jawabnya. Kinerja tidak hanya mengutamakan hasil, namun kinerja juga menilai proses dalam pencapaian hasil tersebut. Berikut ini pendapat para ahli mengenai kinerja.

Stolovitch dan Keeps mengemukakan bahwa kinerja merupakan seperangkat hasil yang dicapai dan merujuk pada tingkatan pencapaian serta pelaksanan sesuatu pekerjaan yang diminta (Hadari Nawawi, 2006:9)

Moh. Pabundu dan Tika (Prawiro Suntoro, 2006:62) menyatakan bahwa kinerja adalah hasil kerja yang dapat dicapai seseorang atau sekelompok orang dalam suatu organisasi dalam rangka mencapai tujuan organisasi dalam rangka mencapai tujuan organisasi dalam periode waktu tertentu

Sedangkan Gibson (2004:75) mengatakan bahwa kinerja (performance) adalah hasil yang diinginkan dari perilaku. Dengan demikian kinerja dapat diartikan sebagai penilaian untuk pencapaian hasil kerja dari yang telah dikerjakan oleh individu atau sekelompok orang di lingkungan kerja demi mencapai tujuan yang telah ditetapkan. Dalam hal ini, penetapan tujuan dibuat oleh perusahaan tempat karyawan bekerja.

Kopelman (Ahmad Ruky, 2002:84) dijelaskan bahwa kinerja selain dipengaruhi oleh faktor lingkungan juga sangat tergantung dari karakteristik individu seperti kemampuan, pengetahuan, keterampilan, motivasi, norma dan nilai, perilaku kerja dan produktivitas kerja, baik individu maupun organisasi. Kemudian Hall TL dan Meija (Ahmad Ruky, 2002:85) menyebutkan bahwa faktor yang mempengaruhi kinerja adalah:

- Faktor internal yang terbagi menjadi dua yaitu karakteristik individu (umur, pendapatan, status perkawinan, pengalaman kerja dan masa kerja) dan

- sikap terhadap tugas (persepsi, pengetahuan, moyivasi, tanggung jawab dan kebutuhan terhadap imbalan (pencapaian target)5.

Selain itu, penilaian kinerja karyawan juga dibatasi oleh waktu kerja selama periode tertentu. Kinerja karyawan dapat dikatakan meningkat apabila hasil yang diperoleh dari pekerjaannya meningkat dan dinilai secara sistematik dari prestasi kerja 
karyawan. Lalu, pendapat lain tentang kinerja karyawan dari berbagi ahli.

Anwar Prabu Mangkunegara (2006:67), faktor yang mempengaruhi pencapaian kinerja adalah faktor kemampuan (ability) dan faktor motivasi (motivation). Hal tersebut sesuai dengan pendapat Keith Davis yang merumuskan bahwa:

- Human Performance = Ability + Motivation

- Motivation $=$ Attitude + Situation

- $\quad$ Ability = Knowledge + Skill

Payaman J. Simanjuntak (2005:84) mendefinisikan kinerja adalah hasil dari kualitatif dan kuantitatif yang dicapai oleh seseorang pegawai dalam melaksanakan tugasnya sesuai dengan tanggung jawab yang diberikan kepadanya.

Dari beberapa pengertian yang dikemukakan di atas dapat ditarik kesimpulan bahwa untuk melakukan penilaian terhadap kinerja seseorang atau kelompok adalah berdasarkan faktor motivasi dan faktor kemampuan baik secara kualitatif maupun kuantitatif.

Menurut teori diatas, kinerja karyawan juga dapat dinilai dari tanggung jawabnya terhadap tugas yang didelegasikan kepada karyawan itu sendiri. Sikap dan situasi pun kini dapat mempengaruhi kinerja karyawan terhadap perusahaannya.

kinerja dapat disimpulkan, kinerja karyawan adalah penilaian hasil kerja selama kurun waktu tertentu sesuai dengan tugas dan pekerjaan yang diberikan untuk mencapai tujuan perusahaan.

\section{Komunikasi Antarpribadi}

Dimanapun berada, setiap orang pasti akan melakukan komunikasi atau berhubungan dengan orang-orang disekitarnya. Oleh karena itu, tidak dipungkiri bahwa kita melakukan komunikasi antarpribadi setiap hari bahkan setiap saat kita berhubungan dan berkomunikasi dengan orang lain. Komunikasi antarpribadi juga terjadi dalam lingkungan pekerjaan. Hal tersebut terjadi karena setiap harinya kita menemui orang-orang yang berbeda. Karyawan yang mampu berkomunikasi dengan baik degan sesama karyaawan,atasan, dan klien mampu untuk memberikan kinerja yang maksimal bagi dirinya. Dibawah ini merupakn pendapat para ahli tentang komunikasi antarpribadi.

Dean C. Barnlund (Wiryanto, 2004:14) mengatakan bahwa komunikasi antarpribadi diartikan sebagai pertemuan antara dua, tiga, atau mungkin empat orang, yang 
terjadi sangat spontan dan tidak berstruktur dan mempunyai ciri-ciri:

1. bersifat spontan,

2. tidak berstruktur,

3. terjadi secara kebetulan,

4. tidak mengejar tujuan yang direncanakan,

5. identitas keanggotaannya tidak jelas,

6. terjadi hanya sambil lalu

Deddy Mulyana (2009:81)

mengemukakan, Komunikasi

antarpribadi (interpersonal

communication) adalah komunikasi antara orang-orang secara tatapmuka, yang memungkinkan setiap pesertanya menangkap reaksi orang lain secara langsung, baik secara verbal ataupun nonverbal dengan bentuk khusus dari komunikasi antarpribadi yaitu; komunikasi diadik yang melibatkan hanya dua orang, seperti suami istri, dua sejawat, dua sahabat dekat,dll.

Komunikasi diadik memiliki ciri-ciri komunikasi didadik adalah: pihakpihak yang berkomunikasi berada dalam jarak yang dekat; pihak-pihak yang berkomunikasi mengirim dan menrima pesan secara simultan dan spontan, baik secara verbal ataupun nonverbal. Liliweri (Syaiful Rohim, 2009:69) menerangkan, komunikasi antarpribadi mempunyai ciri-ciri sebagai berikut:
1. spontan dan terjadi sambil lalu saja (umumnya tatap muka),

2. tidak mempunyai tujuan terlebih dahulu,

3. terjadi secara kebetulan diantara peserta yang tidak mempunyai identitas yang belum tentu jelas,

4. berakibat sesuatu yang disengaja atau tidak disengaja,

5. kerap kali berbalas-balasan,

6. mempersyaratkan ada hubungan paling sedikit dua orang,

7. serta hubungan harus bebas, bervariasi, adanya keterpengaruhan, harus membuahkan hasil, dan menggunakan lambang-lambang bermakna.

Komunikasi antarpribadi merupakan komunikasi yang terjadi secara informal dan bisa terjadi dimanapun dan kapanpun kita berada. Di dalam komunikasi antarpribadi, kita bisa memberkan umpan balik secara langsung terhadap komunikator baik secara verbal ataupun nonverbal dan cenderung terjadi secara spontan dan tatap muka.

Merrill dan Lowstein menyatakan bahwa komunikasi antarpribadi dalam lingkungan pergaulan antar manusia selalu terjadi penyesuaian pikiran, penciptaan simbol yang mengandung pengertian bersama. 
Komunikasi antarpribadi terbentuk atas pergaulan antar sesama manusia karena di dalamnya selalu terjadi pertukaran informasi yang mengandung pengertian bersama sehingga dapat terciptanya hubungan yang baik antar sesama manusia.

Fundamental Interpersonal Relations Orientation (FIRO) yang dikemukakan oleh W.C. Schutz (Yusuf, 2006:131) memusatkan diri pada tiga kebutuhan antarpersona yang sebagian orang merasakannya, yaitu kebutuhan untuk terlibat, pengendalian, dan untuk kasih sayang.

Dengan demikian komunikasi antarpribadi melibatkan dua orang atau lebih yang segera bisa diberikan umpan balik sesuai dengan kebutuhannya. Berikutnya akan dijelaskan teori-teori yang mendukung komunikasi antarpribadi.

\section{Interpersonal Deception}

Theory (David B. Buller dan Judee K. Burgoon): Teori ini menjelaskan bahwa dalam komunikasi antarpribadi sering terjadi penipuan yang digunakan dalam percakapan antara dua orang dan teori ini juga mencoba untuk menjelaskan cara berurusan dengan individu yang sebenarnya menuimbulkan kecurangan pada tingkat kesadaran dan lubuk hati saat melakukan tatap muka komunikasi. (Yusuf, 2006:125)

$$
\text { Pandangan interaksional }
$$
dalam komunikasi antarpersona juga dikenal dengan teori pragmatik (communication pragmatics/ International view) karena proses komunikasi sangat bergantung kepada situasi tertentu yang ada dengan asumsi dasar teori humanistik.

Spitzberg dan Cupach dengan teori Communication Competence (kompetensi komunikasi) yang mengemukakan: Bahwa kompetensi komunikasi adalah suatu kemampuan untuk memilih perilaku komunikasi yang cocok dan efektif bagi situasi tertentu dan dalam komunikasi interpersonal (antarpribadi) memungkinkan dan membolehkan seseorang mencapai tujuan-tujuan komunikasinya tanpa menyebabkan orang lain kehilangan muka dibuatnya. Model yang digunakan meliputi 3 komponen, pengetahuan, keahlian, dan motivasi.

Disini dijelaskan bahwa komunikasi antarpribadi kadang menimbulkan kecurangan dan bersifat humanistik sesuai suasana hati orang yang berkomunikasi dan memunginkan dan membolehkan seseorang mencapai tujuan-tujuan komunikasinya tanpa meyebabkan 
orang lain kehilangan muka atau dengan kata lain saling menghargai. Jesse Delia yang mengemukakan model konstruktivisme yaitu: teori ini bisa menjelaskan bahwa orang yang memiliki persepsi kognitif yang kompleks terhadap orang lain, akan memiliki kapasitas berkomunikasi secara canggih (rumit) dengan hasil yang positif. Selanjutnya Pearce dan Cronan dengan teori Coordinated Management of Meaning mengemukakan bahwa teori ini menjelaskan suatu percakapan (kegiatan komunikasi antar dua orang), dimana para pelaku komunikasinya membentuk realitas sosialnya sendiri dengan cara memperoleh pertalian tertentu, tindakan yang terkoordinasi, serta pengalaman yangtersembunyi atau rahasia (Nasution, Yusriah., 2010 : 20).

\section{Expetancy Violation (Teori} Langgaran) yang dikemukakan oleh Jodee Burgoon: Memandang komunikasi sebagai pertukaran informasi tingkat tinggi dalam hal hubungan isi komunikasi, sehingga bisa digunakan oleh masing-masing pelaku komunikasi untuk menyerang harapan-harapan pihak lawan bicaranya, baik secara positif maupun negatif.
Efektivitas komunikasi mempunyai lima ciri, sebagai berikut:

1. Keterbukaan (openess) yaitu kemauan menanggapi dengan senang hati informasi yang diterima

2. Empati (Empathy) yaitu merasakan apa yang dirasakan orang lain

3. Dukungan (Supportiveness) yaitu situasi terbuka untuk mendukung komunikasi yang efektif

4. Rasa positif (positiveness) yaitu memiliki perasaan yang positif terhadap dirinya sendiri

5. Kesetaraan (equality) yaitu sikap saling menghargai orang lain (Dedy Mulyana, 2009:21)

Michael B. Coyle (Dyah Ayu) menyatakan bahwa Organizations and managers who understand the value of quality interpersonal communications for both short-term and long-term relationships tend to be organizations and managers who lead the others by their superior performance

Para pimpinan dan karyawan yang memelihara hubungan jangka pendek dan jangka panjang dengan komunikasi antarpribadi yang berkualitas akan mampu memimpin orang lain dengan kinerjanya yang luar biasa. 
Ketika proses komunikasi antar komponen (antar pribadi) dapat diselenggarakan secara harmonis, maka perkantoran tersebut semakin kokoh dan kinerja karyawan pun semakin meningkat serta diikuti dengan meningkatnya kinerja perkantoran.

\section{Kecerdasan Emosional}

Karyawan yang cerdas emosinya mampu menangani berbagai permasalahan yang terjadi di dalam pekerjaannya. Sehingga ia mampu mengendalikan diri sehingga ia mampu meyelesaikan masalah dengan solusi yang baik. Berikut ini pendapat para ahli mengenai kecerdasan emosional.

Menurut Daniel Goleman (1995), "kecerdasan emosional adalah kemampuan lebih yang dimiliki seseorang dalam memotivasi diri, ketahanan dalam menghadapi kegagalan, mengendalikan emosi dan menunda kepuasan, serta mengatur keadaan jiwa"

Cooper dan Sawaf (Agus Effendi, 2006:172), kecerdasan emosional adalah kemampuan merasakan, memahami, dan secara selektif menerapkan daya dan kepekaan emosi sebagai sumber energi dan pengaruh yang manusiawi. Meyer dan Salovey dalam Sy dan Cote: Kecerdasan emosional sebagai salah satu bentuk kecerdasan sosial yang meliputi kemampuan untuk memonitor perasaan dan emosi diri sendiri serta orang lain, merasakan perbedaannya dan menggunakan informasi ini sebagai tuntunan dalam berpikir dan mengambil tindakan.

Gareth R. Jones \& Jennifer M. George (2005:31), Emotional Intelligence is the ability to understand and manage one's own moods and emotions and the moods and emotions of other people. Kecerdasan emosional adalah kemampuan untuk mengerti dan mengatur perasaan dan emosi baik diri sendiri maupun orang lain.

Davies, dkk menjelaskan bahwa inteligensi emosi adalh kemampuan seseorang untuk mengendalikan emosi dirinya sendiri dan orang lain, membedakan satu emosi dengan lainnya, dan menggunakan informasi tersebut untuk menuntun proses berpikir serta perilaku seseorang (Daniel Goleman, 1995: 92)

Kemudian, faktor yang juga mempengaruhi "kinerja karyawan adalah kecerdasan emosi seperti Daniel Goleman yang menyimpulkan bahwa pencapaian kinerja ditentukan hanya 20 persen dari IQ sedangkan 80 persen lagi ditentukan oleh kecerdasan emosi." 
Selanjutnya ada Robbin Judge sebagaimana yang dikutip oleh Gareth R.Jones \& Jennifer M. George yang mengemukakan, "a review of fifty-nines studies indicated that, overall, EI (Emotional Intelligence) correlated moderately with job performance." 45 (Dari 59 penelitian semuanya mengindikasikan bahwa Kecerdasan Emosi mempunyai korelasi/hubungan dengan kinerja karyawan).

Sarwono, menyebutkan karyawan dengan EQ yang baik, mempunyai kemampuan pribadi dan sosial seperti empati, disiplin diri, dan inisiatif sehingga akan menghasilkan kinerja yang lebih baik dibandingkan karyawan dengan EQ yang lebih rendah. Kemudian kecerdasan emosional akan mempengaruhi kinerja karyawan karena jika karyawan maupun atasan mampu mengendalikan emosi kita agar tercipta hubungan yang harmonis di perusahaan akan membuat mereka merasa nyaman berada di kantor yang berdampak positif terhadap peningkatan kinerja karyawan itu sendiri.

Sosiolog Komunikasi, Burhan Bungin (2006) mengemukakan: bahwa menemukan orang yang tepat dalam organisasi memang bukan merupakan hal yang mudah, karena yang dibutuhkan perusahaan bukan hanya orang yang berpendidikan lebih baik atau orang yang berbakat saja melainkan ada faktor - faktor psikologis yang mendasari hubungan antara seseorang dengan organisasinya, yaitu kemampuan mengelola diri sendiri, inisiatif, optimisme, kemampuan mengkoordinasi emosi, serta melakukan pemikiran yang tenang tanpa terbawa emosi sehingga tercipta komunikasi interpersonal yang baik untuk pencapaian kinerja yang maksimal di dalam organisasi.

A. A. Anwar Prabu Mangkunegara (2006) mengemukakan: bahwa pimpinan dan karyawan bawahan yang cerdas emosi akan mampu melakukan hubungan interpersonal (antarpribadi) yang sehat dan efektif, tidak hanya menyesuaikan diri dengan lingkungan kerja organisasinya, tetapi ia berusaha keras menciptakan situasi lingkungan yang kondusif agar ia mampu berinovasi dan berkreativitas dalam mencapai kinerja secara maksimal.

\section{Hipotesis Penelitian}

1. Terdapat pengaruh langsung komunikasi antarpribadi terhadap kinerja karyawan di PT. Asuransi Raya

2. Terdapat pengaruh langsung kecerdasan emosional terhadap 
kinerja karyawan di PT. Asuransi Raya

3. Terdapat pengaruh tidak langsung komunikasi antarpribadi terhadap kinerja karyawan melalui kecerdasan emosional di PT. Asuransi Raya.

\section{METODOLOGI PENELITIAN}

Metode penelitian ini menggunakan metode survei korelasional. Metode korelasional adalah meneliti hubungan di antara variabel-variabel. Pada penelitian ini variabel-variabel tersebut adalah komunikasi antar pribadi (X1) dan kecerdasan emosional (X2) terhadap kinerja karyawan (Y).

Populasi dari PT. Asuransi Raya adalah sebanyak 102 orang yaitu jumlah seluruh karyawan. Sample penelitian ini sebanyak 62 orang karyawan. Teknik analisis data dilakukan dengan menganalisa data, dilakukan estimasi parameter Path Analysis yang akan digunakan. Pengolahan data dalam penelitian ini menggunakan program SPSS versi 17.0 .
HASIL DAN PEMBAHASAN Uji Koefisien Jalur (Path Analysis)

Analisis jalur (path analysis) adalah untuk mengetahui pola hubungan antar variabel dengan tujuan untuk mengetahui pengaruh langsung maupun tidak langsung antara variabel independen terhadap variabel dependen. Diagram jalur (path analysis) dan persamaan struktur komunikasi antarpribadi dan kecerdasan emosi terhadap kinerja karyawan sebagai berikut:

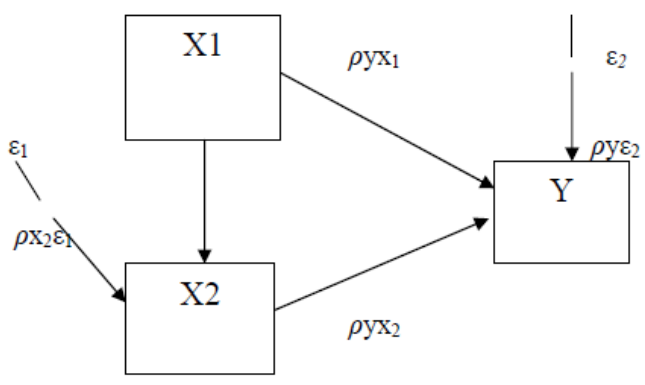

Sehingga didapat persamaan strukturnya sebagai berikut:

Struktur: Y: $\rho y \times 1 X 1+\rho y \times 2 X 2+$

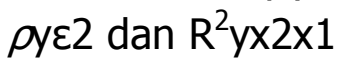

Dimana $\mathrm{X} 2=\rho \times 2 \times 1 \times 1+\rho \times 2 \varepsilon 1$ dan $\mathrm{R}^{2} \times 2 \times 1$ 


\section{Rangkuman Hasil Koefisien Jalur}

\begin{tabular}{|c|c|c|c|c|c|}
\hline $\begin{array}{l}\text { Pengaruh } \\
\text { Antar } \\
\text { Variabel }\end{array}$ & $\begin{array}{c}\text { Koefisien } \\
\text { Jalur (Beta) }\end{array}$ & & Pengujian & $\begin{array}{c}\text { Koefisien } \\
\text { Determina } \\
\text { n atau } \\
\mathbf{R}_{\text {square }}\end{array}$ & $\begin{array}{l}\text { Koefisien } \\
\text { Variabel lain } \\
\text { (sisa) }\end{array}$ \\
\hline \multicolumn{4}{|c|}{$\begin{array}{l}\text { Dependen : Kinerja } \\
\text { Independent : Komunikasi Antarpribadi dan } \\
\text { Kecerdasan Emosi }\end{array}$} & $\mathrm{R}^{2} \mathrm{yx}_{2} \mathrm{x}_{1}$ & $\rho y \epsilon_{2}$ \\
\hline \multicolumn{2}{|l|}{$\mathrm{X}_{1}-\mathrm{Y}$} & 417 & Ho ditolak & \multirow[t]{2}{*}{0,386} & $0,784^{2}$ \\
\hline $\mathrm{X}_{2}-\mathrm{Y}$ & & 324 & Ho ditolak & & $=0,614$ \\
\hline \multicolumn{4}{|c|}{$\begin{array}{l}\text { Dependent : Komunikasi Antarpribadi } \\
\text { Independent : Kecerdasan Emosi }\end{array}$} & $\mathbf{R}^{2} \mathbf{x}_{2} \mathrm{x}_{1}$ & $P \mathrm{x}_{2} \epsilon_{1}$ \\
\hline \multicolumn{2}{|c|}{$\begin{array}{l}\mathrm{X}_{1}-\mathrm{X}_{2} \\
\text { (Pearson Correlation) }\end{array}$} & 397 & Ho ditolak & 0,158 & $\begin{array}{l}0,918^{2} \\
=0.842\end{array}$ \\
\hline
\end{tabular}

Maka, berdasarkan tabel di atas dapat digambarkan sebagai berikut:

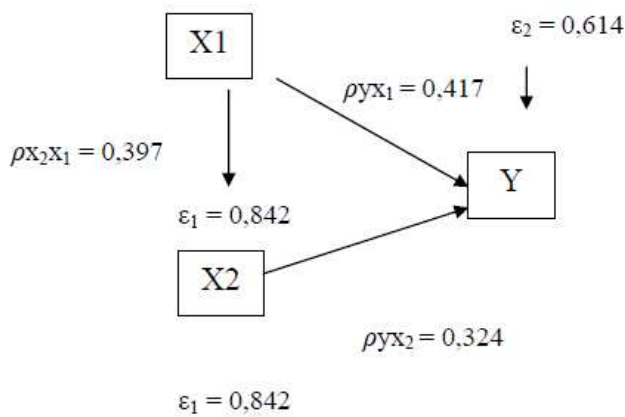

Sehingga didapat persamaan strukturnya sebagai berikut: Struktur $Y=0,417 \mathrm{X} 1+0,324 \mathrm{X} 2+$ $0,614 \quad \varepsilon_{2}$ dan R2yx2x1=0,614 Dimana X2 $=0,397 X 1+0,842 \varepsilon_{1}$ dan $\mathrm{R} 2 \times 2 \times 1=0,158$

Berdasarkan hasil perhitungan analisis jalur struktur tersebut, maka memberikan insformasi secara objektif sebagai berikut:

1) Besarnya kontribusi komunikasi antarpribadi (X1) yang secara langsung mempengaruhi kinerja (Y) adalah $0,4172=0,174$ atau $17,4 \%$

2) Besarnya kontribusi kecerdasan emosional (X2) yang secara langsung mempengaruhi kinerja (Y) adalah 0,3242 =0,105 atau $10,5 \%$.

3) Besarnya pengaruh komunikasi antarpribadi (X1) terhadap (Y) dengan dimoderatori oleh kecerdasan emosional (X2) sebesar $\rho \times 2 \times 1 . \rho y \times 2=(0,397)$. $(0,324)=0.128$.

Dengan demikian pengaruh total komunikasi antarpribadi (X1) dan kecerdasan emosional (X2) berpengaruh secara simultan yang langsung mempengaruhi kinerja $(\mathrm{Y})$ 
adalah $0,386=38,6 \%$. Sisanya sebesar $61,4 \%$ dipengaruhi faktorfaktor lain yang tidak dapat dijelaskan dalam penelitian.

Untuk lebih jelasnya mengenai koefisien jalur tersebut dapat dilihat pada table di bawah ini

\begin{tabular}{|c|c|c|c|c|}
\multicolumn{5}{|c|}{ Analisis Jalur } \\
\cline { 2 - 4 } Variabel & $\begin{array}{c}\text { Koefisien } \\
\text { Jalur }\end{array}$ & Langsung & $\begin{array}{c}\text { Tengaruh Y } \\
\text { Tidak } \\
\text { Langsung } \\
\text { Melalui } \mathbf{X}_{2}\end{array}$ & \\
\hline $\mathrm{X}_{1}$ & $\mathbf{0 , 4 1 7}$ & $\mathbf{0 , 1 7 4}$ & $\mathbf{0 , 1 2 8}$ & - \\
\hline $\mathrm{X}_{2}$ & $\mathbf{0 , 3 2 4}$ & $\mathbf{0 , 1 0 5}$ & - & - \\
\hline$\epsilon_{1}$ & $\mathbf{0 , 8 4 2}$ & $\mathbf{0 , 9 1 8 ^ { 2 } = 0 , 8 4 2}$ & - & - \\
\hline$\epsilon_{2}$ & $\mathbf{0 , 6 1 4}$ & $\mathbf{0 , 7 8 4 ^ { 2 } = 0 , 6 1 4}$ & - & $\mathbf{0 , 3 8 6}$ \\
\hline
\end{tabular}

\section{Uji Hipotesis}

Uji $F$ atau uji koefisien regresi secara serentak digunakan untuk mengetahui pengaruh signifikan variabel independen secara serentak terhadap variabel dependen apakah berpengaruh secara signifikan atau tidak. Hipotesis penelitiannya:

Variabel komunikasi antarpribadi dan kecerdasan emosional karyawan berkontribusi secara simultan dan signifikan terhadap kinerja.

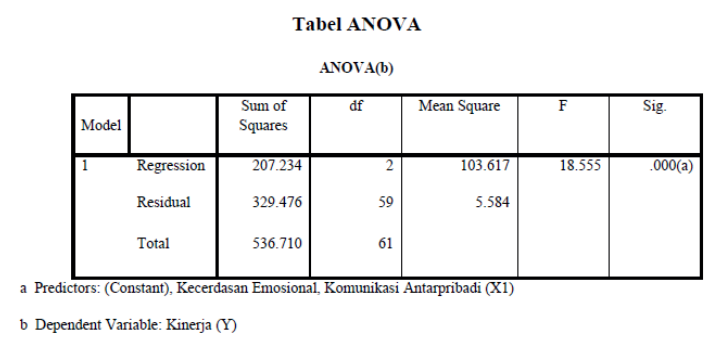

Berdasarkan tabel Anova di atas, didapatkan $\mathrm{F}$ hitung sebesar 18.555. Sedangkan besarnya $F$ tabel dapat dilihat pada tabel statistic dengan signifikansi $0,05 \mathrm{df} 1=\mathrm{k}-1$ atau 3-1, dan df2= n-k-1 atau 62-21=59 Didapat $F$ tabel adalah 3,15. Sehingga diketahui $F$ hitung $(18,555)>F$ tabel $(3,15)$, artinya Ho ditolak dan Ha diterima.

Sehingga dapat disimpulkan komunikasi antarpribadi dan kecerdasan emosional berkontribusi secara simultan dan signifikan berpengaruh terhadap kinerja.

$\mathrm{Uji} \mathrm{t}$ digunakan untuk mengetahui pengaruh variabel independent secara parsial terhadap variabel dependen, apakah pengaruhnya signifikan atau tidak. Hipotesis penelitiannya berupa:

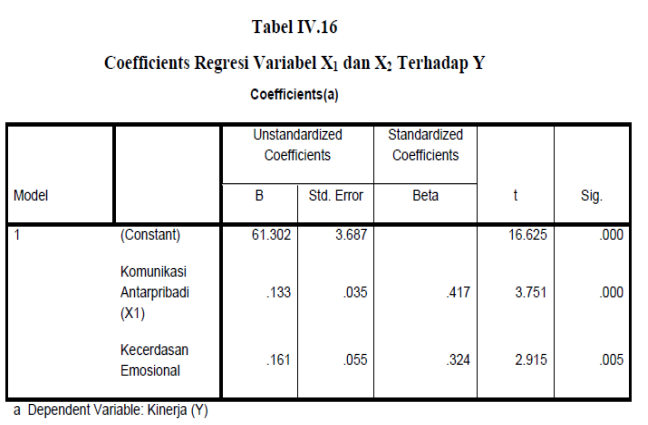

Uji t dapat dilihat dalam tabel koefisien regresi linear di atas, berdasarkan hasil output tersebut diperoleh thitung dari komunikasi antarpribadi sebesar 3,751 dan ttabel dapat dicari pada tabel statistik pada signifikansi 0,05 dengan $d f=n-k-1$ atau $62-2-1=59$, maka didapat $t_{\text {tabel }}$ sebesar 2.00 . 
Dapat diketahui bahwa thitung dari komunikasi antarpribadi $(3,751)$ $>t_{\text {tabel }}(2,00)$ jadi hipotesis nol ditolak, kesimpulannya yaitu komunikasi antarpribadi berkontribusi secara signifikan terhadap kinerja.

Selain itu, berdasarkan hasil output di atas dapat diketahui bahwa thitung dari kecerdasan emosional $(2,915)>t_{\text {tabel }}(2,00)$ jadi hipotesis nol ditolak, kesimpulannya yaitu kecerdasan emosional mempunyai pengaruh yang signifikan terhadap kinerja.

\section{KESIMPULAN}

Komunikasi antarpribadi adalah interaksi antara dua orang atau lebih secara tatap muka. Hal tersebut seringkali terjadi secara kebetulan dan para komunikan mampu memberikan umpan balik kepada komunikator secara langsung. Selain itu komunikasi antarpribadi juga memiliki ciri-ciri terbuka, empati, penuh dukungan, rasa yang positif dan terakhir kesetaraan satu sama lain yang mempengaruhi kinerja pada karyawan PT. Asuransi Raya. Kecerdasan emosi merupakan kemampuan diri untuk mengontrol perasaan, menjaga emosi sehingga kita mampu mengendalikan sikap serta dapat membuat kita menjadi perilaku baik serta dapat membuat kita menjadi perilaku baik serta mampu mengerti perasaan orang lain yang memberikan kontribusi terhadap peningkatan kinerja pada karyawan PT. Asuransi Raya.

Dengan demikian hubungan positif antara komunikasi antarpribadi dan kecerdasan emosi terhadap kinerja karyawan tidak terjadi secara kebetulan. Semakin baik komunikasi antarpribadi yang terjalin diantara karyawan,maka kinerja karyawan menngkat. Begitu juga, semakin tinggi tingkat kecerdasan emosi, maka kinerja pada karyawan meningkat. Terdapat hubungan tidak langsung antara komunikasi antarpribadi dengan kinerja karyawan melalui kecerdasan emosi yang akan berakibat pada peningkatan kinerja karyawan. Sehingga dapat disimpulkan bahwa terdapat pengaruh yang positif antara komunikasiantarpribadi dan kecerdasan emosi terhadap kinerja karyawan PT. Asuransi Raya.

\section{DAFTAR PUSTAKA}

Bungin, Burhan.2006. Sosiologi Komunikasi

(Teori,

Paradigma, dan Diskursus Teknologi Komunikasi di Masyarakat). Jakarta: Kencana Prenada Media Group 
Davies, dkk., 2002. Mengajarkan Emotional Intelegence Pada Anak, Jakarta; Pustaka Utama.

DeVito, Joseph A. Komunikasi Antarmanusia. Edisi kelima. Alih Bahasa Agus Maulana MSM. Jakarta: Professional Books

Dyah, Ayu Neng dan Mario Oktaviani. Hubungan Komunikasi Interpersonal Antar Pegawai Terhadap Kinerja Pegawai. Jakarta

Effendi, Agus., 2006. Revolusi Kecerdasan Abad 21. Alfabeta, Jakarta.

Gareth R. Jones \& Jennifer $M$. George-Ekman P., 2008. Emotional Awareness. New York; Times Books.

Goleman, Daniel., 2001. Emotional Intelligence. New York.

Hadari, Nawawi. 2006. Evaluasi dan Manajemen Kinerja di Lingkungan Perusahaan dan Industri.Yogyakarta: Gadjah Mada University Press.

Hechanova, Ma. Regina.M dan Edna P. Franco. Leading Philippine Organizations In A Changing World.Manila: Ateneo de Manilla University Press

James Gibson. James H Donelly, dll. 2003. Organisasi: Perilaku Struktur, proses Jilid I Jakarta: Binarupa Aksara,
Mangkunegara, A. A. Anwar Prabu. 2006., Manajemen Sumber Daya Manusia Perusahaan. Bandung: Rosda.

Martin, Anthony Dio., 2005. Melatih Kecerdasan Emosi. Jakarta.

Mulyana, Deddy., 2009. IImu Komunikasi, Remaja Rosdakarya, Bandung

Nasution, Yusriah. 2010. Komunikasi Antarpribadi. Jakarta: Laboratorium Sosial Politik Press Universitas Negeri Jakarta,

Onong Uchjana, 2006M. IImu Komunikasi Teori dan Praktek, Remaja Rosdakarya, Bandung,

Rivai, Veithzal. 2004. Manajemen Sumber Daya Manusia untuk Perusahaan. Jakarta: PT. Raja Grafindo Persada,

Rohim, H. Syaiful. M.Si, 2009. Teori Komunikasi: Perspektif, Ragam, \& Aplikasi. Jakarta. PT. Rineka Cipta

Ruky. , Ahmad. 2002. Sistem Manajemen Kinerja. Jakarta : Gramedia Pustaka Utama

Sembel, Roy. 2005. Bagaimana Membangun Komunikasi Dua Arah.Jakarta

Simanjuntak, Payaman J. 2005. Manajemen dan Evaluasi Kinerja. Jakarta: Fakultas Ekonomi Universitas Indonesia. 
Tika, Moh. Pabundu. 2006. Budaya Organisasi dan Peningkatan Kinerja Perusahaan. Jakarta: PT. Bumi Aksara

Wiryanto. 2004. Pengantar Ilmu Komunikasi. Jakarta: PT. Grasindo
Yusup, Pawit M., 2006, IImu Informasi, Komunikasi, dan Kepustakaan, Bumi Aksara, Bandung. 